\title{
A Study on Ethics of Collective Responsibility in Japan's High School Baseball: An Examination from the Viewpoint of Communitarianism
}

\author{
Mitsuharu Omine ${ }^{1}$ and Hidenori Tomozoe ${ }^{2}$ \\ ${ }^{1}$ Graduate School of Sport Sciences, Waseda University; \\ Research Fellow of Japan Society for the Promotion of Science, \\ 2-579-15, Mikajima, Tokorozawa, Saitama 359-1192, Japan \\ E-mail: 20431604@toki.waseda.jp \\ ${ }^{2}$ Faculty of Sport Sciences, Waseda University, \\ 2-579-15, Mikajima, Tokorozawa, Saitama 359-1192, Japan \\ [Received December 21, 2012; Accepted June 10, 2013; Published online June 25, 2013]
}

\begin{abstract}
In this study, we focus on a discussion of whether collective responsibility in high school baseball is right or wrong, analyzing the point at issue from the viewpoint of communitarianism and aiming to provide a new viewpoint for the argument. We selected the obligation concept as a concrete perspective for our analysis and used it to examine the point at issue.

The crucial issue was whether a person who is a member of a baseball club should take responsibility for the actions of other members of the same baseball club. First, we reviewed criticism of communitarianism to moral individualism. Second, we clarified the obligation concept as defined by Sandel, who is a representative of the communitarian viewpoint. Finally, we used that concept to frame the issue mentioned above.

As a result, we propose that members of a baseball club have obligations of solidarity toward one another in terms of their communities, which in this case are both the baseball club and the school.
\end{abstract}

Keywords: moral individualism, MacIntyre, narrative conception, Sandel, obligations of solidarity

\section{Introduction}

When members of a school baseball club affiliated to the Student Baseball Group*1 are involved in a scandal, the Japan Student Baseball Association (JSBA) may consider putting the club on suspension.

The second paragraph of Article 29 of Chapter 7 of the Japan Student Baseball Charter (JSBC) explicitly states that, in the event of club members or club coaches violating the provisions, the JSBA can punish the entire club*2.

In recent years, however, where there has been no organized involvement by multiple members, as a general rule, punishment has been limited to the centrally responsible players or coaches, and there has been a shift away from the notion of the team as a whole bearing responsibility, with it more likely to be acquitted of culpability (Ochiai, 2011). Nakamura (2010), who shows the transitional change that has occurred in the number of scandals in Japanese high school baseball from 1954 through 2009, points out that there has been a continuous weakening of the infliction of punishment based on concepts of collective responsibility. Hirotaka Nishioka, Chairman of the Review Board of the Japan High School Baseball Federation (JHSBF)*3 has indicated that the JHSBF will consider a scandal to be a group problem rather than a personal problem if the disgraced members number five or more ("Shape Japan," 2007). This is not unequivocal, however, for there may be exceptions. For example, in a case in which younger students have been damaged by club violence, for example, Nishioka insists that they will have a chance to take part in the match next year (“Shape Japan," 2007). 
The problem of collective responsibility is often brought into question in high school baseball, but examples of collective responsibility also exist in university sports. For instance, the Inter-University Athletic Union of Kanto revoked the eligibility of the Nippon Sport Science University's track and field club to enter the Hakone Ekiden relay marathon as a result of the involvement of a member of the club, specializing in a field event, in a marijuanarelated incident ("Nippon Sport," 2009). Elsewhere, the involvement of a Kinki University boxing club member in a robbery caused the university to disband the entire club ("Breakup Kinki," 2009).

The Goningumi system*4, previously in place in Japan, has led to a widespread tendency to accept collective responsibility. In recent years, however, the imposition of collective responsibility has been subject to considerable criticism.

Sakamoto (1990) insists that the justification for imposing collective responsibility in high school baseball is because relationships of dominance*5, dating from the pre-modern era, still remain, and that the imposition of collective responsibility is a barbaric act (pp. 135-139). He argues that it is common sense, as codified in modern law, to take responsibility only for one's own action, and not to take responsibility for the actions of other persons (Sakamoto, 1995, p. 223).

In the world of journalism, the imposition of collective responsibility tends to be criticized on the principle that responsibility should only be taken for one's own actions ${ }^{* 6}$. According to the principle of self-responsibility, the scope for which an individual person accepts responsibility is limited by that person's previous agreements or the consequences of his or her own actions (Takikawa, 1999, p. 120). In modern times, moral individualism on the principle of self-responsibility has achieved ascendancy.

However, in the context of imposed collective responsibility, is it possible to chalk its responsibility up to a barbaric act? Feinberg (1970) states that individual liability is not eternal $\operatorname{law}^{* 7}$ (p. 241). Takikawa (1999) also points out that collective responsibility is not a convention of the pre-modern era which needs to be overcome, and that intellectual efforts need to be made to consider the possibilities of how collective responsibility can be justified (p. 126).

Tadera (2010) conducted a study about collective responsibility in high school baseball. He demon- strated the opinions of coaches in each baseball club on the question of the suspension of collective responsibility, but the study did not consider the ethics of this responsibility. Until now, discussion regarding the ethics of imposition of collective responsibility in high school baseball has been limited to the media, and only a few cases have been considered in sport philosophy.

The problem of collective responsibility can be summed up in two broad questions (Takikawa, 1999, pp. 124-125). The first is whether moral responsibility belongs to groups, such as nations, companies, and schools. The second is whether personal responsibility is generated by affiliation to one of those groups. In this study, we will limit our consideration to the latter issue. Specifically, we will focus on whether a member belonging to a certain baseball club should take responsibility for the actions of other members belonging to the same baseball club.

This study is intended to suggest a new viewpoint in the issue of the ethics of collective responsibility in high school baseball by examining it from the perspective of communitarianism ${ }^{* 8}$, which takes a critical stance on moral individualism. In particular, the problem of personal versus collective responsibility in the context of baseball clubs is discussed within a communitarian framework. We focus on the concept of obligation, which may serve as an effective analytical viewpoint in discussing the ethics of collective responsibility.

This study was conducted according to the following procedure. First, critique of moral individualism by communitarianism is reviewed. Second, we make a comparison of the concepts of obligation proposed by Rawls and Sandel. Lastly, we consider the obligation of baseball club members from the viewpoint of Sandel's concept of obligation.

\section{Criticism of communitarianism to moral individualism}

MacIntyre (1984) is critical of moral individualism. He cites as examples of such individualism the denial by modern Americans of their responsibility for slavery, the denial by the modern English of their responsibility for the Irish invasion, and the denial by modern Germans of their responsibility for the acts of the Nazi party (p. 220). His position is that the self, from the viewpoint of individualism, is 
detachable from its social and historical roles and statuses (MacIntyre, 1984, p. 221). His position is set out below:

For the story of my life is always embedded in the story of those communities from which I derive my identity. I am born with a past; and to try to cut myself off from that past, in the individualist mode, is to deform my present relationships ... self has to find its moral identity in and through its membership in communities such as those of the family, the neighborhood. (MacIntyre, 1984, p. 221)

Sandel (2009) points out that MacIntyre's narrative conception of person offers a clear contrast with the voluntarist conception of persons as freely choosing, unencumbered selves (p. 223). He suggests that the two conceptions may be assessed by asking which offers a more convincing account of moral obligation. In the next section, the idea of obligation is considered in terms of these two conceptions.

\section{Sandel's criticism of obligation as defined by Rawls}

\subsection{Obligation as defined by Rawls}

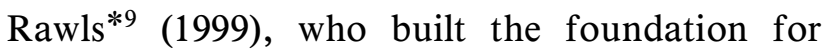
twentieth century liberalism, points out three characteristics of obligations, presented in contrast to natural duties ${ }^{* 10}$ (p. 97). First, obligations arise as a result of voluntary acts. By contrast, natural duties may be characterized by the fact that they apply to us without regard to voluntary acts (Rawls, 1999, p. 98). Second, the content of obligations is always defined by an institution or practice. On the contrary, natural duties have no necessary connection with institutions or social practices. Third, obligations are normally owed to those who are cooperating together to maintain the arrangement in question. Rawls (1999) also makes the following comment:

We acquire obligations by promising and by tacit understandings, and even when we join a game, namely, the obligation to play by the rules and to be a good sport. (p. 97)

In other words, central to the idea of obligations as defined by Rawls (1999) is whether there was any agreement with other people and, if so, who they were*11. According to Rawls' notion of obligation, current generations may not accept responsibility for historic injustices inflicted on others by their state. This is because they do not agree to accept responsibility for historic injustices by the state.

\subsection{Obligation as defined by Sandel}

In this section, we review about the representative debater, Sandel, who critiques Rawls and supports collective responsibility.

Sandel (2009) insists that the liberal account of obligation is too weak from the standpoint of the narrative conception of the person (p. 224). He argues that the liberal account fails to consider the special responsibilities which we have to one another as fellow citizens, and fails to capture those loyalties and responsibilities. He suggests that the moral force of these loyalties consists partly in the fact that living by them is inseparable from understanding ourselves as a particular person*12. These identities are not contingencies we can set aside when deliberating about morality and justice (Sandel, 2009, p. 224).

According to Sandel (2009), the decision between the voluntarist and narrative conceptions of the person can be made by asking if there is a third category of obligations (p. 224). He calls these obligations of solidarity, or membership, and describes them as shown below:

[they] can't be explained in contractarian terms. Unlike natural duties, obligations of solidarity are particular, not universal; they involve moral responsibilities we owe, not to rational beings as such, but to those with whom we share a certain history. But unlike voluntary obligations, they do not depend on an act of consent. Their moral weight derives instead from the situated aspect of moral reflection, from a recognition that my life story is implicated in the stories of others. (Sandel, 2009, p. 225)

Sandel (2009) divides moral responsibility into three categories (p. 225). The first category comprises natural duties. Those duties are universal, and do not require consent. This category is similar to the concept of natural duties to be defined by Rawls. The second category is voluntary obligations ${ }^{* 13}$. Those obligations are particular and require consent. This category is also similar to the concept of obligations as defined by Rawls. The third category is obligations of solidarity*14. Those obligations are particular and do not require consent. This category entails a concept of obligations not discussed by 
Rawls.

From Sandel's perspective, the claim of collective responsibility for historic injustices is meant to challenge the contractarian idea that we are the authors of the only those moral obligations that constrain us (Sandel, 2009, pp. 240-241). He points out that it would be difficult to live, or to make sense of our lives, without the claim of solidarity, and that it is difficult to account for the claim of solidarity from the viewpoint of moral individualism, since they cannot be captured by an ethic of consent. As Sandel (2009) puts it:

We've been trying to figure out whether all our duties and obligations can be traced to an act of will or choice. I've argued that they cannot; obligations of solidarity or membership may claim us for reasons unrelated to a choice-reasons bound up with the narratives by which we interpret out lives and the communities we inhabit. (p. 241)

Until now, the grounds for criticizing the imposition of collective responsibility in high school baseball have been based on the idea of obligation for liberalism, as shown by Rawls (1999). Reconsidering that responsibility from the idea of obligation in the context of communitarianism, as proposed by Sandel (1998, 2009, 2010), may provide a valuable new viewpoint.

\section{Analysis of collective responsibility in high school baseball in the context of Sandel's obli- gation}

In this section, collective responsibility in high school baseball is discussed from the viewpoint of obligation as shown by Sandel (1998, 2009, 2010). Specifically, we focus on the example of the collective responsibility to be imposed in the case of club violence by multiple members. The reason for selecting this example for analysis is because the JSBA has regularly suspended clubs which have allowed violence*15.

School baseball clubs joining the Student Baseball Group qualify to take part in student baseball qualification by agreeing to the provisions of the JSBC. That is, when there is a violation of Article 29 of Chapter 7 of the JSBC by the members or the coaches of a baseball club, those members or coaches may agree themselves to the punishment determined by the JSBA. From the viewpoint of such an agreement, they may be seen to have a voluntary obligation to observe the provisions of the JSBC.

On the other hand, it is difficult for the members and the coaches who are in mutual pursuit of excellence to choose to play baseball outside the jurisdiction of the JHSBF. That is because most of the high school baseball clubs in Japan join the JHSBF. There are, therefore, doubts about whether the members and the coaches are indeed subject to the provisions of the JSBC voluntarily. Joining the JHSBF and observing the provisions of the JSBC could actually be interpreted as de facto coercion.

Such an interpretation is also based on the grounds upon which the coaches might have a query about any collective responsibility imposed by the JSBA. For example, Coach Watanabe of the Yokohama High School baseball club points out that it is too severe for a student who has been disciplined through his or her own school regulations to be further penalized by the JSBA ("Shape Japan," 2008). From his perspective, it is more important for the JSBA to formulate guidelines and then to leave actual punishment to the school. In this scenario, the case of club violence by multiple members may not fall into the category of voluntary obligation, in which the other members are also subject to the imposition of suspension.

Next, collective responsibility is analyzed from the perspective of obligations of solidarity. As noted previously, the narrative conception of a person is the position that the self is not detachable from its social and historical roles and statuses. According to this conception, being a member of the baseball club and the school is to assume its social and historical roles. In other words, being a member of the baseball club and the school as a community imposes obligations of solidarity as loyalties and responsibilities which each member has to the others. From Sandel's perspective, such obligations are particular and do not require consent. That is, if there is club violence by multiple members, other members have imposed upon them obligations of solidarity, despite that violence not having been their choice*16.

\section{Conclusion}

In this study, the ethics of collective responsibility as observed in Japanese high school baseball was examined from the viewpoint of communitarianism. 
As a result, it was suggested that the members of a baseball club have obligations of solidarity toward one another as members of shared communities, which are the baseball club and the school respectively. It may be said that the members of clubs in other sport except a baseball also have obligations of solidarity.

On the other hand, communitarianism is criticized from a liberalist perspective in that the idea may become oppressive for the freedom of the members of a community (Oba et al., 2006, p. 190). Furthermore, the possibility of removing the individual who did not share the good of the community is pointed out (Oba et al., 2006, p. 308). Communitarianism applies to certain aspects in baseball, but may be limited by liberal concerns in other instances that may limit cases of solidarity. The future challenge is to examine this problem for communitarianism.

The imposition of collective responsibility examined in this study was only considered in the context of club violence by multiple members. The JSBA also regularly suspends clubs where its members have been engaged in smoking and drinking ${ }^{* 17}$. The analysis, from a variety of viewpoints, of various cases of the collective responsibility imposed in smoking and drinking cases is a task for the future.

\section{Acknowledgments}

This study was supported by Waseda University Global COE program "Sport Sciences for the Promotion of Active Life."

\section{Notes}

*1 The Student Baseball Group includes the Japan Student Baseball Association, the All Japan University Baseball Federation and the Japan High School Baseball Federation (Japan Student Baseball Association [JSBA], 2011, p. 3).

*2 The JSBA establishes the JSBC as the operational standards applicable to high school baseball and university baseball (JSBA, 2011, p. 2).

*3 The JSBA provides guidance and advice based on the JSBC for to the JHSBF (JSBA, 2011, p. 5).

*4 In the Edo period (1603-1868), groups of five people were held collectively responsible, so that when one of five people could not pay tribute to the Edo Shogunate, the remaining four people were required to pay the shortfall (Irimoto, 2009, p. 2).

*5 As examples of dominance, the relationship between superior and soldier in the military forces of the prewar era is shown (Sakamoto, 1990, p. 135). Sakamoto (1990) insists that the responsibility in the situation isn't based on free will and exists as obedience duty for the orders (p. 135).

*6 For example, Daisuke Nagai, Mainichi Newspaper correspondent, and sports journalist Seijun Ninomiya entertain doubts about imposing collective responsibility on baseball club members (Nagai, 2005; "Komazawa Univer- sity," 2006).

*7 Eternal law means a universal law that applies anytime, anywhere.

*8 The concept of communitarianism used in this study is not majoritarianism, which affirms the opinion of the many in a specific area in a particular era. It is the position that an individual person bears a variety of concrete attributions, such as family, nation, and community, and always has a relationship with others. Representative scholars of communitarianism include MacIntyre and Sandel (Mulhall and Swift, 1992). Sandel (1998) has denied that his position should be termed communitarian (p. ix), but equally he has stated that, in the definition of communitarianism mentioned above, his position is communitarian in nature (Sandel, 1996/2010, pp. 217-218).

*9 The idea that takes responsibility only for one's own action, and not to take responsibility for the actions of other persons is based on the concept of liberalism. An effective suggestion can be seen about collective responsibility by analyzing Rawls who is representative scholar in liberalism.

*10 As examples of natural duties, the duty of helping another when he is in jeopardy and the duty not to injure another are shown (Rawls, 1999, p. 98).

*11 The view of Rawls (1999) is based on the conception that have to be content with a vague formula stating that justice is what be agreed to without being able to say much, if anything, about the substance of the agreement itself (p. 121).

*12 "Particular person" here refers to oneself as members of that family or nation or people; as bearers of that history; as citizens of that republic (Sandel, 2009, p. 224).

*13 As examples of voluntary obligations, the duty of painting for a person when he agrees to paint the house is shown (Sandel, 2009, p. 224).

*14 As examples of obligations of solidarity, the obligation are shown in terms of family members and the particular communities (Sandel, 2009, pp. 225-240).

*15 For example, the JSBA suspended Okinawa Shogaku High School for three months in response to club-based violence perpetrated by six members in the baseball club ("Japan Student," 2011). Furthermore, the JSBA suspended Konosu High School for two months for the assault of younger students by six senior students ("JSBA Punishments," 2012).

*16 We will discuss in other article whether obligations of solidarity justify the penalty by JSBA or not.

*17 For example, the JSBA suspended Totomisogo High School for one month in response to members of the baseball club smoking ("JSBA Suspending," 2012). Additionally, the JSBA suspended Sawa High School for three months in response to members of the baseball club drinking alcohol (“Japan Student,", 2010).

\section{References}

Breakup of Kinki University Boxing Club. (2009, June 18). Yomiuri Newspaper, p. 13. (in Japanese)

Feinberg, J. (1970). Doing and deserving: Essays in the theory of responsibility. Princeton, NJ: Princeton University Press. Irimoto, M. (2009). 5ningumi to kinsei sonraku: Rentai sekininsei no rekishi [Goningumi system and modern village: History of collective responsibility]. Tokyo: Yuzankaku. (in Japanese)

Japan Student Baseball Association. (2011). The directory of Japan student baseball. Tokyo: Japan Student Baseball 
Association. (in Japanese)

JSBA: Punishments of eleven high schools. (2011, October 7). Mainichi Newspaper, p. 19. (in Japanese)

JSBA: Punishments of one college and fifteen high schools. (2010, September 11). Mainichi Newspaper, p. 19. (in Japanese)

JSBA: Punishments of seven high schools. (2012, July 6). Mainichi Newspaper, p. 19. (in Japanese)

JSBA: Suspending six high schools which caused club violence. (2012, June 9). Mainichi Newspaper, p. 19. (in Japanese)

Komazawa University Tomakomai High School declines Japanese High School Baseball Invitational Tournament. (2006, March 4). Asahi Newspaper, p. 39. (in Japanese)

MacIntyre, A. C. (1984). After virtue (2nd ed.). Notre Dame, IN: University of Notre Dame Press.

Mulhall, S., and Swift, A. (1992). Liberals and communitarians: An introduction. Oxford, UK: John Wiley and Sons.

Nagai, D. (2005, October 14). Kisha Mai column: Punishments for the scandal in Japan student baseball. Mainichi Newspaper, p. 26. (in Japanese)

Nakamura, T. (2010). Gakusei yakyu kensho towa nanika: Jichi kara miru nihon yakyushi [What is the Japan Student Baseball Charter?: Japan baseball history in the light of autonomy]. Tokyo: Seikyusya. (in Japanese)

Nippon Sport Science University accepts the adjudication of the Inter-University Athletic Union of Kanto. (2009, April 28). Yomiuri Newspaper, p. 19. (in Japanese)

Oba, T., Inoue, T., Kato, H., Kawamoto, T., Kanzaki, S., Shionoya, Y., and Narita, K. (Eds.). (2006). Gendai rinrigaku jiten [Encyclopedia of contemporary ethics]. Tokyo: Kobundo. (in Japanese)

Ochiai, H. (2011, October 17). Shasetsu: Collective responsibility of abusive language. Mainichi Newspaper, p. 5. (in Japanese)

Rawls, J. (1999). A theory of justice (Rev. ed.). Cambridge, MA: Harvard University Press.

Sakamoto, H. (1990). Kosoku no hanashi: Seito no tame no kenri tokuhon [Story of school regulation: Right handbook for students]. Tokyo: San-ichi Publishing. (in Japanese)

Sakamoto, H. (1995). Taibatsu no kenkyu [Study of physical punishment]. Tokyo: San-ichi Publishing. (in Japanese)

Sandel, M. J. (1998). Liberalism and the limits of justice (2nd ed.). Cambridge, MA: Cambridge University Press.

Sandel, M. J. (2009). Justice: What's the right thing to do? New York: Farrar, Straus \& Giroux.

Sandel, M. J. (2010). Democracy's discontent: America in search of a public philosophy (M. Kimpara, and K. Kobayashi,Trans.). Tokyo: Keiso Shobo. (Original work published 1996)

Shape of Japan high school baseball (Pt. 1, No. 6). (2007, December 8). Asahi Newspaper, p. 21. (in Japanese)

Shape of Japan high school baseball (Pt 6, No. 2) (2008, October 1). Asahi Newspaper, p. 18. (in Japanese)

Tadera, Y. (2010). A study about educational judgments which the High School Baseball Federation has passed to scandal: An analysis of the comparison between the Japan High School Baseball Federation and the All Japan High School Athletic Federation. Taiiku Tetsugaku Kenkyu, 40, 25-35. (in Japanese)

Takikawa, H. (1999). Kojin jiko sekinin no gensoku to shugoteki sekinin [The principle of individual self responsibility and collective resoponsibility]. In T. Inoue, I. Shimazu and Y. Matsuura (Eds.), Hojissen eno teigen [New visions for legal practices] (pp. 119-139). Tokyo: University of Tokyo Press. (in Japanese)

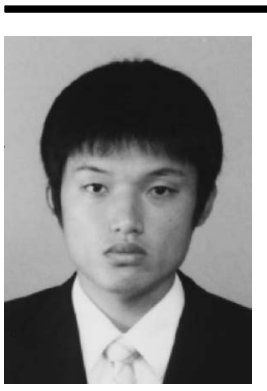

Name:

Mitsuharu Omine

\section{Affiliation:}

Graduate School of Sport Sciences, Waseda University; Research Fellow of Japan Society for the Promotion of Science

\section{Address:}

2-579-15, Mikajima, Tokorozawa, Saitama 359-1192, Japan

Brief Biographical History:

2011-current Doctoral program in Graduate School of Sport Sciences, Waseda University, Japan

2013-current Research Fellow of Japan Society for the Promotion of Science

Main works:

-Mitsuharu, O., Hidenori, T., and Yusuke, O. (2012) A study on right or wrong of "foul game" in basketball: With focus on the controversy between Fraleigh and Simon. Japanese Journal of Sport Education Studies, 31(2), 13-25.

Membership in Learned Societies:

- Japan Society of Physical Education

- Japanese Society of Sport Education

- Japan Society for the Pedagogy of Physical Education

-Japan Society for the Philosophy of Sport and Physical Education 